\title{
How much is Teaching and Learning in Higher Education Digitized? Insights from Teacher Education
}

\author{
Jens Riehemann ${ }^{1}$ \& Regina Jucks ${ }^{1}$ \\ ${ }^{1}$ University of Münster, Germany \\ Correspondence: Jens Riehemann, University of Münster, Department of Psychology and Sport Studies, Fliednerstr. \\ 21, 48149 Münster, Germany
}

Received: May 18, 2017

Accepted: June 4, 2017

Online Published: June 6, 2017

doi:10.5430/ijhe.v6n3p129

URL: https://doi.org/10.5430/ijhe.v6n3p129

\begin{abstract}
The digital age has changed how we communicate, inform ourselves, and even how we teach and learn. This study systematically analyses and compares the perspectives of university academics $(N=75)$ and university students $(N=$ 206) from the field of teacher education on digitized teaching and learning. In a between-subjects design, participants of both groups were asked for their perspectives on dealing with digital media (i.e., general assessment of digital media, use of different media types and the role of digital media in university courses). Furthermore, they were asked for their own and their anticipated perspectives of each other, in particular, their assumed advantages of using digital media in university teaching. In sum, the findings indicate that it might be fruitful for university academics and students to exchange their views on the use of digital media for teaching and learning in higher education.
\end{abstract}

Keywords: Higher education, Digital media, Teacher education, University academics, University students

\section{Introduction}

As a result of the "digital revolution" (Zysman \& Newman, 2006) of the twenty-first century, we have been living in an increasingly digitized era, with technological developments of digital media affecting every aspect of our personal and working lives - especially our communication habits (Michikyan, Subrahmanyam, \& Dennis, 2015; Thompson, 2013). This has changed people and interaction behaviour (Jones, Ramanau, Cross, \& Healing, 2010). In this paper, the term "digital media" serves as an umbrella term that comprises all electronic devices and applications, which enable users to create, retrieve, process, distribute or exchange information. This means, that there are numerous possibilities for distributing and receiving information. Whereas information exchange with digital media requires a specific know-how (Merluzzi, 2014), there is currently no standardized concept for what constitutes "digital competence" (Ilomäki, Paavola, Lakkala, \& Kantosalo, 2016). Nevertheless, using digital media is already an important part of teaching and studying (Park \& Burford, 2013; Goeze, Zottmann, Vogel, Fischer, \& Schrader, 2014). University academics and students make use of both, informal and formal means of digital communication (Margaryan, Littlejohn, \& Vojt, 2011; Trinder, Guiller, Margaryan, Littlejohn, \& Nicol, 2008). Prior research (Roblyer, McDaniel, Webb, Herman, \& Witty, 2010) showed that both groups differ on using especially social media tools (e.g., Facebook): Students are more likely to use such tools whereas university academics prefer conventional media like E-mail. However, negative effects of social media usage on students' well-being have also been reported (Lau, 2017; Meier, Reinecke, \& Meltzer, 2016).

Therefore, those in higher education are challenged to keep up with accelerating technological innovations, especially when it comes to the implementation of digital media (Martin, 2012; Toro \& Joshi, 2012). But, how do those involved perceive this challenge? Recently, university administrators (Jungermann, Osterfeld, Scholz, Villiez, \& Wannemacher, 2016) and students (Persike \& Friedrich, 2016) took part in large-scale German surveys, in which they were asked for their views on the digitization of higher education. While university administrations tended to favour strengthening the link between digital media and teaching, students' use of digital media in courses depended on specifically what was offered by university academics. Given that students' experiences depend on how university academics use and think about technology, it might be beneficial to compare both groups' (students' and academics') opinions about technology in order to inform best practices for future use of digital media in teaching and learning in higher education (e.g., see Waycott, Bennett, Kennedy, Dalgarno, \& Gray, 2010; Päuler-Kuppinger \& Jucks, 2017). 
The current study investigated the perspectives of university academics and students on digital media in higher education, specifically of university academics and students in the field of teacher education. Two online surveys were conducted to identify whether both groups differ in their perspectives on digital media.

\section{Method}

\subsection{Participants and Design}

Participants consisted of university academics and students, who were teaching or studying, respectively, in the field of teacher education. One student was excluded from the sample, because the participant indicated that the answers should not be used for further analyses.

\subsubsection{University academics.}

Participants were $N=75$ university academics $(58.7 \%$ male) with a mean age of 40.65 years $(S D=11.49)$. Around half of them were actually teaching bachelor's and master's degree students (49.3\%). Most of them (75.7\%) reported to have more than a 50\% position at the university. Furthermore, all university academic participants had a median teaching experience of 9 semesters in teacher education, with values ranging from 1 to 76 semesters of teaching experience. In the winter semester of 2016/2017, their median teaching responsibilities were 6 semester hours per week, with values ranging from 1 to 22 semester hours per week.

\subsubsection{Students.}

Participants were $N=206$ students $(65.0 \%$ female) with a mean age of 23.16 years $(S D=3.16)$. All students had a median study time of 5 semesters in teacher education, with values ranging from 1 to 18 semesters. Most of them (72.8\%) were bachelor's degree students. In the winter semester of 2016/2017, they had median studying responsibilities of 18 semester hours per week, with values ranging from 0 to 38 .

All participants were recruited from a large university in western Germany via E-mail lists and newsletters addressed to either university academics or students in the field of teacher education. Participants took part in one of two online surveys via hyperlink (university academic or student version). Online surveys were designed and hosted via the platform Questback EFS Survey. Upon completion of the survey, participating university academics were given the opportunity to enter a prize drawing for the chance to win one of several USB flash drives; each participating student was compensated with a $5 €$ Amazon ${ }^{\circledR}$ voucher.

\subsection{Procedure and Materials}

Prior to participating in the respective online survey, all participants were given detailed information on the procedure and data usage and provided informed consent.

\subsection{Dependent Measures}

At the beginning of both online surveys, demographic data were collected.

\subsubsection{General assessment of digital media.}

Using a 5-point Likert scale (ranging from $1=$ very low to $5=$ very high) participants were asked to self-evaluate their competence in handling digital media. Then, they were asked to rate to what extent (in percentage) digital media is used and should be used in university courses. Participants were also asked to answer an open question, which was used to compare perspectives of university academics and students: "What opportunities and risks do you see in using digital media in university teaching?" All answers were analysed for how many opportunities and risks were identified by one independent coder (student assistant). Furthermore, participants were asked to rate their satisfaction with using digital media in university courses [asked to university academics] or in their studies [asked to students] (5-point Likert scale, ranging from $1=$ very dissatisfied to $5=$ very satisfied).

\subsubsection{Use of digital media types.}

The individual use of different types of digital media was assessed by an adapted version of a media type scale from Persike and Friedrich (2016). In particular, participants were asked whether and which of five digital media types they used in their university courses / studies and their leisure time. Media types were:

1. Conventional digital media and communication tools (e.g., E-mails, PowerPoint, PDF, or subject-specific data bases),

2. Social communication tools (e.g., blogs, chats, forums, or social networks like Facebook),

3. Electronic test systems (e.g., E-assessments and E-exams), 


\section{Audio-/video-based media and tutorials (e.g., podcasts, YouTube), and}

5. Interactive tools and formats (e.g., Wikis, web-conferences, online-office tools such as Google Drive, educational games).

\subsubsection{Role of digital media.}

An adapted version of a single-item scale from Jungermann et al. (2016) was used to assess participants' general opinion on the role of digital media in university courses / studies (7-point Likert scale, ranging from $1=$ none at all to 7 = very high; Appendix A). Furthermore, an adapted version of a questionnaire on guiding principles of digital teaching from Jungermann et al. (2016) was used to identify how digital media is employed for teaching and learning in university courses / studies (e.g., "In my teaching, I selectively enrich certain classroom sessions with digital elements (enrichment concept)" [version for university academics], "In my studies, certain classroom sessions are selectively enriched with digital elements (enrichment concept)" [version for students]").

\subsubsection{Advantages of using digital media.}

To assess participants' opinions on the advantages of using digital media in university teaching, an adapted version of the questionnaire from Paechter, Fritz, Maier, and Manhal (2007) was applied by using a 5-point Likert scale (ranging from $1=$ correct to $5=$ not correct; Appendix B). The scale contains six subscales: didactic design ( 6 items; e.g., "clarity and conciseness of class and learning materials"), tutorial support (5 items; e.g., "learning support and, if necessary, guidance from academic"), individual learning support (5 items; e.g., "usability of learning platform"), learning success (5 items; e.g., "acquisition of subject-specific skills and knowledge"), and communication and cooperation (3 items; e.g., "Personal contact between / to other students"). This scale was given two times in a row, in which the introductory question and specific single items were reframed in order to create a change of perspective from that of the participant ("Which advantages do you see in using digital media in university teaching?") to that of the other participating group (either the university academic or the student) ("What do you think: Which advantages do [students/university academics] see in using digital media in university teaching?").

\section{Results}

An alpha level of .05 was used for all statistical tests and a Kolmogorov-Smirnov goodness-of-fit test was used to check whether the data were normally distributed. All reported results are two-tailed.

\subsection{General Assessment of Digital Media}

According to the rating scale, self-evaluation of competence in handling digital media was above average for the whole sample $(M=3.78, S D=0.84)$. An independent-samples t-test indicated no difference between university academics $(M=3.81, S D=0.91)$ and students $(M=3.77, S D=0.81)$ in their self-evaluation of competence, $t(279)=$ $0.410, p=.682, n s$.

A Mann-Whitney $U$ test revealed that university academics $(M d n=100 \%)$ and students $(M d n=80 \%)$ differ in how much they currently use digital media in university courses, $U=2923.5, p<.001, r=.42$. That is, university academics rated that they currently use digital media more often in university courses than students do. A similar pattern was also found regarding the desired use of digital media: Here, another Mann-Whitney $U$ test also showed that university academics $(M d n=100 \%)$ desire to use digital media in courses more than students $(M d n=90 \%)$ do, $U=4328.5, p<.001, r=.28$. Within the student group, a Wilcoxon signed-rank test showed that students say they desire to use digital media more than they currently think it is being used in university courses, $Z=5.121, p<.001, r$ $=.36$. This means, that students would prefer even more use of digital media. By contrast, university academics did not indicate that they desired more use of digital media above the current level (no difference between current and desired use of digital media in university courses), $Z=0.422, p=.673, n s$.

For the open question regarding opportunities and risks associated with using digital media in university teaching, a Mann-Whitney $U$ test revealed that university academics $(M d n=2)$ listed more opportunities as a result of using digital media than did students $(M d n=1), U=4929.5, p=.011, r=.16$. Furthermore, another Mann-Whitney $U$ test showed that university academics $(\mathrm{Mdn}=1)$ also listed more risks regarding the use of digital media in university teaching than did students $(M d n=1), U=4915.5, p=.008, r=.17$. Thus, university academics reported that they see opportunities on an organizational level (e.g., comfortable way of distributing materials), on a didactic level (e.g., varied possibilities for knowledge sharing), and on an individual level (e.g., supporting learning according to students' own time and space). With regard to the risks, university academics raised some concerns about the potential loss of personal contact, the potential overemphasis of media compared to content, and had general 
concerns about technical difficulties due to a lack of competence on the part of both students and university academics.

Moreover, both groups reported above average satisfaction with using digital media in university courses $(M=3.80$, $S D=0.86)$. In addition, an independent-samples t-test revealed that university academics $(M=3.88, S D=0.98)$ and students $(M=3.77, S D=0.81)$ did not differ on their satisfaction ratings, $t(279)=0.973, p=.331, n s$.

\subsection{Use of Digital Media Types}

Nearly all university academics reported to use conventional digital media and communication tools in their courses (98.7\%) and in their leisure time (97.3\%) as did students $95.6 \%$ in courses; $98.8 \%$ in leisure time. Social communication tools were used by $20 \%$ of university academics in their courses and by $48 \%$ in their leisure time. In contrast, these social communication tools were used by $70.9 \%$ of students in their studies and by $92.2 \%$ in their leisure time. Furthermore, university academics rarely use electronic test systems $(5.3 \%)$ in their courses or in their leisure time (1.3\%). In comparison, $16.5 \%$ of all students use electronic test systems in their studies, and $6.3 \%$ of students use them in their leisure time. Of all university academics, $52 \%$ reported to use audio-/video-based media and tutorials in their courses and $69.3 \%$ used them in their leisure time. Somewhat similarly, $43.2 \%$ of students reported that they use audio-/video-based media and tutorials in their studies and $71.8 \%$ use them in their leisure time. Finally, while interactive tools and formats are used by only $14.7 \%$ of university academics in their courses and by $25.3 \%$ in their leisure time, interactive tools and formats are used by $30.1 \%$ of students in their studies and by $35 \%$ of students in their leisure time.

\subsection{Role of Digital Media}

The role of digital media in university courses was rated as having above-average importance (on the mentioned rating scale) for both groups $(M=5.25, S D=1.31)$. An independent-samples t-test indicated no differences between university academics $(M=5.12, S D=1.50)$ and students $(M=5.30, S D=1.24)$ on their opinions of how important digital media is in university courses or studies, respectively, $t(278)=-1.028, p=.305, n s$.

Of all university academics, only $6.7 \%$ reported that they provide classroom teaching without enrichment with digital elements. Most university academics (52\%) reported to selectively enrich certain classroom sessions with digital elements, while $49.3 \%$ reported that they pursue a blended-learning approach-one that systematically enriches classroom teaching with digital components. Overall, only 5.3\% of university academics selectively pursue an approach of just online teaching. Furthermore, $32 \%$ of all university academics agree that digital media should decisively contribute to helping students overcome challenges, such as by helping to increase their study success. Only $12 \%$ of university academics reported that they have another central idea.

From the students' point of view, 5.3\% of students reported that classroom teaching done entirely without enrichment with digital elements. Most students, $63.1 \%$ of them reported that certain classroom sessions are selectively enriched with digital elements, while $44.2 \%$ of students indicated that a blended-learning approach is used in their classroom settings. Only $8.3 \%$ of students reported that an online-only teaching approach is used in their courses. Furthermore, $17.5 \%$ of students agree that digital media can decisively contribute to helping students overcome challenges; while $2.4 \%$ reported that they have another central idea.

\subsection{Advantages of Using Digital Media}

\subsubsection{University Academics' and Students' Perspectives on the Advantages of Using Digital Media}

An independent-samples t-test indicated that university academics $(M=2.38, S D=0.86)$ and students $(M=2.16, S D$ $=0.78$ ) differ on how advantageous they believe digital media to be regarding the subscale tutorial support, $t(279)=$ 2.005, $p=.046, d=0.27$, which refers to feedback quality and academic availability: Students believe that digital media offers more advantages regarding tutorial support than university academics do. However, a Mann-Whitney $U$ test revealed that university academics $(M d n=1.7)$ are more likely to believe that digital media offers benefits for didactic design than are students $(M d n=2), U=5238.5, p<.001, r=.25$. Here, didactic design refers to the quality of communicative support and the supply of learning materials. Regarding the subscale individual learning support, an independent-samples t-test indicated that university academics $(M=2.30, S D=0.84)$ and students $(M=2.20, S D$ $=0.75)$ do not differ, $t(279)=0.871, p=.385, n s$, on how much they believe digital media can encourage autonomous learning. In addition, another independent-samples t-test, on the subscale learning success indicated that university academics $(M=2.54, S D=0.89)$ and students $(M=2.23, S D=0.69)$ differ in how much believe digital media affects the acquisition of skills, $t(279)=3.055, p=.008, d=0.39$. That is, students were more likely than university academics to agree that digital media contributes to learning success. Finally, an independent-samples t-test for the subscale communication and cooperation indicated that students $(M=2.04, S D=0.76)$ were more 
likely than university academics $(M=2.31, S D=0.81)$ to agree that digital media encourages the exchange of information between students, $t(279)=2.612, p=.009, d=0.34$.

\subsubsection{Anticipated Perspectives of the Other Group on the Advantages of Using Digital Media}

An independent-samples t-test indicated that university academics $(M=2.16, S D=0.93)$ and students $(M=1.99, S D$ $=0.75)$ do not differ on the subscale tutorial support, $t(279)=1.412, p=.161, n s$. Another independent-samples t-test also revealed that university academics $(M=1.73, S D=0.63)$ and students $(M=1.68, S D=0.55)$ do not differ on the subscale didactic design, $t(279)=0.730, p=.466$, $n s$. Furthermore, a Mann-Whitney $U$ test showed differences between university academics $(M d n=2.4)$ and students $(M d n=2.2)$ on the subscale individual learning support, $U=6445, p=.033, r=.13$. Students anticipated that university academics are likely to believe that digital media impact individual learning support. In contrast, university academics believe that students would not expect their learning outcome to be influenced by individual learning support. Another independent-samples t-test indicated that university academics $(M=2.15, S D=0.78)$ and students $(M=2.03, S D=0.69)$ do not differ on the subscale learning success, $t(279)=1.215, p=.225$, ns. Finally, an independent-samples t-test indicated that university academics $(M=2.32, S D=0.96)$ and students $(M=2.20, S D=0.79)$ do not differ on the subscale communication and cooperation, $t(279)=0.947, p=.346, n s$.

\section{Discussion}

The present study shows that university academics and students have different perspectives about the use of digital media. Within the general assessment of digital media, results indicate that university academics and students feel an average level of competence in their handling of digital media. In line with Ilomäki et al. (2016), this shows that "digital competence" is still a fuzzy set of measures - guiding standards are missing. In addition, university academics think that the level to which digital media is used in university courses is appropriate. In contrast, students stated that the overall level to which digital media is used within university courses is good, but should be extended in the future. Furthermore, and compared to students, university academics reported a higher amount of opportunities and risks associated with using digital media for teaching: On the one hand, university academics mainly reported that digital media offers ways to organize materials and learning opportunities. On the other hand, university academics also stated that using digital media might generate negative consequences, such as reduce personal contact, introduce potential conflicts of form or content and might also lead to problems when university academics and students lack competence with the digital media.

The use of digital media types indicates that university academics and students differ on their use of media types for university matters and leisure time: university academics, for example, reported to use social communication tools more often in their leisure time than for their courses. This is in line with Tess (2013), who found that university academics use social media in higher education less often than expected. Furthermore, students reported to use social communication tools within their studies more than three times as often as university academics (see also Roblyer et al., 2010). As such, students' use of digital media depends on what is offered by the university academics (Persike \& Friedrich, 2016), and, in accordance with Trinder et al. (2008), when a course lacks such offerings, students frequently use the tools that are directly available to them. Furthermore, approximately half of all university academics and students use audio/video-based media and tutorials for university teaching and studying, and about 70\% of both groups use this media in their leisure time. Interactive tools and formats are occasionally used, but students use them more often than university professors, both in studies and in leisure time. Electronic test systems are rarely used by either group, which may be related to the examination regulations in the field of teacher education.

Results regarding the role of digital media indicate nearly the same findings for both university academics and students: The two extremes, teaching and studying without digital elements as well as an online-only teaching do not exist in practice. Note, this result might be different at Distance Learning Universities (e.g., FernUniversität Hagen in Germany, Open University). At traditional universities, this study indicates that it is very common to enrich classroom sessions with digital elements and also use blended-learning approaches. Blended-learning is compatible with common higher education settings and supports both effectiveness and efficiency of learning (Garrison \& Kanuka, 2004). Moreover, nearly $1 / 5$ of all university academics in our sample-almost twice the number of students who shared this belief - agree that digital media can help solve current challenges that students face.

Looking at the subscales of the advantages of using digital media, results show that university academics and students rather differ on their own perspectives than on their perspectives of each other. Regarding their own perspectives, university academics are more likely than students to believe that digital media can promote didactic design; whereas students are more likely than university academics to believe that digital media is beneficial for aspects regarding tutorial support, learning success, and communication and cooperation. These results might be 
explained by the different foci of both groups: whereas university academics are more interested in how to design their university courses, students are more aimed at supporting their studies.

When changing perspectives, students only stated that university academics would be more likely to think that digital media can benefit individual learning support: That indicates that students consider digital media's ability to support aspects of individual learning to be more important for university academics compared to university academics' view of students. There were no differences between both groups on all other subscales. In other words, university academics and students showed very similar results when anticipating each other's perspectives. With regard to the findings of Northcote (2009), this could imply that both groups might have rather idealistic views of each other when it comes to teaching and learning with digital media. In accordance with Waycott et al. (2010), university academics and students might benefit from discussing their perspectives on using digital media in order to support teaching and learning in higher education.

\subsection{Limitations and Suggestions for Future Research}

The results of this study are limited by the fact that they were only based on a small sample from the field of teacher education from a large university in western Germany. In particular, university academics and students within the field of teacher education might possess a higher awareness of teaching and learning processes than university academics and students of other subjects. Nevertheless, our results provide first indications that comparing university academics' and students' views on digital media may generate fruitful insights for developing digitally supported learning opportunities in higher education.

Based on this work, we are interested in further investigating how using digital media in university courses is viewed by university academics and students from other disciplines in order to understand how their specific use may support teaching and learning in university courses. To learn more about those perspectives, our future studies will place further emphasis on qualitative measures.

\section{Conclusion}

Our results indicate that students would prefer more digital media in their studies. University academics reported more opportunities as well as risks associated with the specific use of digital media in university teaching. Students reported to use social communication tools frequently for both their studies and leisure time. With regard to the advantages of using digital media in university teaching, university academics emphasized that aspects of didactic design are important for them, whereas students focused on tutorial support, learning success, and communication and cooperation. When students and university academics were asked about each other's perspectives on the advantages of using digital media, we found that both groups might have rather idealistic views of each other. Therefore, the results suggest that the quality of teaching and learning in higher education may especially benefit in case where university academics and students exchange their perspectives on the use of digital media. Hence, digital wisdom must be taught (Prensky, 2009) - and it must be discussed.

\section{Acknowledgments}

We thank Anna Brinker for research assistance. We thank Katrin Burmester and Inja Vetter for help with data processing. Furthermore, we thank Celeste Brennecka for language editing and Gesa Linnemann for translating materials.

\section{References}

Garrison, D. R., \& Kanuka, H. (2004). Blended learning: Uncovering its transformative potential in higher education. The Internet and Higher Education, 7(2), 95-105. https://doi.org/10.1016/j.iheduc.2004.02.001

Goeze, A., Zottmann, J. M., Vogel, F., Fischer, F., \& Schrader, J. (2014). Getting immersed in teacher and student perspectives?: Facilitating analytical competence using video cases in teacher education. Instructional Science, 42(1), 91-114. https://doi.org/10.1007/s11251-013-9304-3

Ilomäki, L., Paavola, S., Lakkala, M., \& Kantosalo, A. (2016). Digital competence - an emergent boundary concept for policy and educational research. Education and Information Technologies, 21(3), 655-679. https://doi.org/10.1007/s10639-014-9346-4

Jones, C., Ramanau, R., Cross, S., \& Healing, G. (2010). Net generation or Digital Natives: Is there a distinct new generation entering university? Computers \& Education, 54(3), 722-732. https://doi.org/10.1016/j.compedu.2009.09.022 
Jungermann, I., Osterfeld, S., Scholz, J., von Villiez, A., \& Wannemacher, K. (2016). Organisation Digitaler Lehre in den Deutschen Hochschulen [Organization of digital teaching in German universities]. Hochschulforum Digitalisierung. https://hochschulforumdigitalisierung.de/sites/default/files/dateien/HFD _AP_Nr21_Organisation_digitaler_Lehre_web.pdf

Lau, W. W. (2017). Effects of social media usage and social media multitasking on the academic performance of university students. Computers in Human Behavior, 68, 286-291. https://doi.org/10.1016/j.chb.2016.11.043

Margaryan, A., Littlejohn, A., \& Vojt, G. (2011). Are digital natives a myth or reality?: University students' use of digital technologies. Computers \& Education, 56(2), 429-440. https://doi.org/10.1016/j.compedu.2010.09.004

Martin, F. G. (2012). Will massive open online courses change how we teach? Communications of the ACM, 55, 26-28. https://doi.org/10.1145/2240236.2240246

Meier, A., Reinecke, L., \& Meltzer, C. E. (2016). "Facebocrastination"?: Predictors of using Facebook for pro-crastination and its effects on students' well-being. Computers in Human Behavior, 64, 65-76. https://doi.org/10.1016/j.chb.2016.06.011

Merluzzi, A. (2014). How to make online learning effective. APS Observer. http://www.psychologicalscience.org/ index.php/video/how-to-make-online-learning-effective.html.

Michikyan, M., Subrahmanyam, K., \& Dennis, J. (2015). Facebook use and academic performance among college students: A mixed-methods study with a multi-ethnic sample. Computers in Human Behavior, 45, 265-272. https://doi.org/10.1016/j.chb.2014.12.033

Northcote, M. (2009). Educational beliefs of higher education teachers and students: Implications for teacher education. Australian Journal of Teacher Education, 34(3), 69-81. http://doi.org/10.14221/ ajte.2009v34n3.3

Paechter, M., Fritz, M. B., Maier, M. B., \& Manhal, M. S. (2007). eSTUDY-eLearning im Studium: Wie beurteilen und nutzen Studierende eLearning? [eStudy-eLearning in university studying: How students are evaluating and using eLearning?]. https://wissenschaft.bmwfw.gv.at/uploads/tx_contentbox/estudy_endbericht.pdf

Paechter, M., \& Maier, B. (2010). Online or face-to-face? Students' experiences and preferences in e-learning. The Internet and Higher Education, 13(4), 292-297. https://doi.org/10.1016/j.iheduc.2010.09.004

Päuler-Kuppinger, L. \& Jucks, R. (2017). Perspectives on teaching: Conceptions of teaching and epistemological beliefs of university academics and students in different domains. Active Learning in Higher Education, 18(1), 63-76. https://doi.org/ 10.1177/1469787417693507

Park, S., \& Burford, S. (2013). A longitudinal study on the uses of mobile tablet devices and changes in digital media literacy of young adults. Educational Media International, 50(4), 266-280. https://doi.org/10.1080/09523987.2013.862365

Persike, M., \& Friedrich, J. D. (2016). Lernen mit digitalen Medien aus Studierendenperspektive [Learning with digital media from the student's perspective] Hochschulforum Digitalisierung. https://hochschulforumdigitalisierung.de/sites/default/files/dateien/HFD_AP_Nr_17_Lernen_mit_digitalen_Me dien_aus_Studierendenperspektive.pdf

Prensky, M. (2009). H. Sapiens Digital: From Digital Immigrants and Digital Natives to Digital Wisdom. Innovate: Journal of Online Education, 5(3). http://nsuworks.nova.edu/innovate/vol5/iss3/1

Roblyer, M. D., McDaniel, M., Webb, M., Herman, J., \& Witty, J. V. (2010). Findings on Facebook in higher education: A comparison of college faculty and student uses and perceptions of social networking sites. The Internet and Higher Education, 13(3), 134-140. https://doi:10.1016/j.iheduc.2010.03.002

Tess, P. A. (2013). The role of social media in higher education classes (real and virtual) - A literature review. Computers in Human Behavior, 29(5), A60-A68. https://doi.org/ 10.1016/j.chb.2012.12.032

Thompson, P. (2013). The digital natives as learners: Technology use patterns and approaches to learning. Computers \& Education, 65, 12-33. https://doi.org/10.1016/j.compedu. 2012.12.022

Toro, U., \& Joshi, M. (2012). ICT in Higher Education: Review of Literature from the Period 2004-2011. International Journal of Innovation, Management and Technology, 3(1), 20-23.

Trinder, K., Guiller, J., Margaryan, A., Littlejohn, A., \& Nicol, D. (2008). Learning from digital natives: bridging formal and informal learning. Higher Education, 1, 1-57. 
Waycott, J., Bennett, S., Kennedy, G., Dalgarno, B., \& Gray, K. (2010). Digital divides? Student and staff perceptions of information and communication technologies. Computers \& Education, 54(4), 1202-1211. https://doi.org/10.1016/j.compedu.2009.11.006

Zysman, J., \& Newman, A. (2006). How revolutionary was the digital revolution? National responses, market transitions, and global technology. Palo Alto, CA: Stanford University Press.

\section{Appendices}

Appendix A. Role of digital media (adapted scale from Jungermann et al. (2016), translated from German)

We are interested in your opinion: What importance do you assign to digital teaching to your current university courses / studies?

$\square$ none at all $\quad \square \quad \square \quad \square \quad \square \quad \square \quad \square \quad$ very high $\quad \square$ no statement

In the following, please choose those aspects that are characteristic for the employment of digital teaching in your university courses / studies. [Find student version in italics and in round square brackets]

$\square$ In my teaching, I merely provide classroom teaching (without enrichment with digital elements).

[In my studies, it is merely providing classroom teaching (without enrichment with digital elements).]

$\square$ In my teaching, I selectively enrich certain classroom sessions with digital elements (enrichment concept).

[In my studies, certain classroom sessions are selectively enriched with digital elements (enrichment concept).]

$\square$ In my teaching, I pursue a blended-learning approach: classroom teaching is systematically enriched with digital components. [In my studies, a blended-learning approach is pursued: classroom teaching is systematically enriched with digital components.]

$\square$ In my teaching, I selectively pursue an approach of mere online teaching. [In my studies, an approach of mere online teaching is selectively pursued.]

$\square$ Digital teaching should decisively contribute to the solution of latest challenges for students (i.e., increase of study success, improvement of quality). [Digital teaching should decisively contribute to the solution of latest challenges in my studies (i.e., increase of study success, improvement of quality).]

$\square$ Another central idea, namely 
Appendix B. Advantages of using digital media (example: university academics version of the adapted scale from Paechter, Fritz, Maier, and Manhal (2007), translated from German).

(1) What do you personally consider to be the advantages of the use of digital media in higher education?

(2) Finally, please put yourself in the position of students.

What do you think students consider to be the advantages of the use of digital media in higher education?

[Find reframed items in italics and in square brackets]

\begin{tabular}{|c|c|c|c|c|c|}
\hline & Agree & & $\begin{array}{l}\text { Partly } \\
\text { agree }\end{array}$ & & $\begin{array}{l}\text { Do not } \\
\text { agree }\end{array}$ \\
\hline $\begin{array}{l}\text { Easy and fast exchange of information and knowledge (via email, } \\
\text { chat, forum, etc.) among [with other] students }\end{array}$ & $\square$ & $\square$ & $\square$ & $\square$ & $\square$ \\
\hline Promotion of joint learning between participants & $\square$ & $\square$ & $\square$ & $\square$ & $\square$ \\
\hline Personal contact between students & $\square$ & $\square$ & $\square$ & $\square$ & $\square$ \\
\hline $\begin{array}{l}\text { Autonomy regarding way of studying, learning strategies and } \\
\text { learning speed }\end{array}$ & $\square$ & $\square$ & $\square$ & $\square$ & $\square$ \\
\hline Opportunity to autonomous practice and studying & $\square$ & $\square$ & $\square$ & $\square$ & $\square$ \\
\hline $\begin{array}{l}\text { Opportunity for students to test their own learning gain (e.g., using } \\
\text { tests) [Opportunity to test one's own learning gain...] }\end{array}$ & $\square$ & $\square$ & $\square$ & $\square$ & $\square$ \\
\hline Usability of learning platform & $\square$ & $\square$ & $\square$ & $\square$ & $\square$ \\
\hline $\begin{array}{l}\text { Support of students' motivation (e.g., by academics, through } \\
\text { feedback, self-assessment, etc.) [Support of one's own motivation...] }\end{array}$ & $\square$ & $\square$ & $\square$ & $\square$ & $\square$ \\
\hline $\begin{array}{l}\text { Acquisition of skills regarding scientific work with computer and } \\
\text { internet (e.g., online research) }\end{array}$ & $\square$ & $\square$ & $\square$ & $\square$ & $\square$ \\
\hline Acquisition of subject-specific skills and knowledge & $\square$ & $\square$ & $\square$ & $\square$ & $\square$ \\
\hline Acquisition of practice-oriented knowledge & $\square$ & $\square$ & $\square$ & $\square$ & $\square$ \\
\hline Acquisition of communicative and cooperative skills & $\square$ & $\square$ & $\square$ & $\square$ & $\square$ \\
\hline Acquisition of skills regarding autonomous learning and studying & $\square$ & $\square$ & $\square$ & $\square$ & $\square$ \\
\hline Good availability of academic via email, chat, forum, etc. & $\square$ & $\square$ & $\square$ & $\square$ & $\square$ \\
\hline $\begin{array}{l}\text { Multimedia and varied knowledge sharing (via images, graphics, } \\
\text { animations, etc.) }\end{array}$ & $\square$ & $\square$ & $\square$ & $\square$ & $\square$ \\
\hline $\begin{array}{l}\text { Opportunity for students to decide to learn when and where they } \\
\text { want to learn [Opportunity to decide to learn when and where you } \\
\text { want] }\end{array}$ & $\square$ & $\square$ & $\square$ & $\square$ & $\square$ \\
\hline Clarity and conciseness of class and learning materials & $\square$ & $\square$ & $\square$ & $\square$ & $\square$ \\
\hline Completeness and currency of learning materials & $\square$ & $\square$ & $\square$ & $\square$ & $\square$ \\
\hline $\begin{array}{l}\text { Varied offer of communication tools for participants (e.g., email, } \\
\text { chat, forum) }\end{array}$ & $\square$ & $\square$ & $\square$ & $\square$ & $\square$ \\
\hline Good cost-efficiency ratio between learning efforts and learning gain & $\square$ & $\square$ & $\square$ & $\square$ & $\square$ \\
\hline Fast feedback from academic (via email, chat, forum, etc.) & $\square$ & $\square$ & $\square$ & $\square$ & $\square$ \\
\hline Learning support and, if necessary, guidance from academic & $\square$ & $\square$ & $\square$ & $\square$ & $\square$ \\
\hline $\begin{array}{l}\text { Good and extensive introduction into the course (information about } \\
\text { learning platform, course organization) }\end{array}$ & $\square$ & $\square$ & $\square$ & $\square$ & $\square$ \\
\hline Opportunity for personal contact between students and academic & $\square$ & $\square$ & $\square$ & $\square$ & $\square$ \\
\hline Good availability of academic via email, chat, forum, etc. & $\square$ & $\square$ & $\square$ & $\square$ & $\square$ \\
\hline
\end{tabular}

Note. Subscales: Items 1-3 (communication and cooperation); items 4-8 (individual learning support); items 9-13 (learning success); items 14-19 (didactic design); items 20-24 (tutorial support). 